\title{
Seleksi Beasiswa Untuk Perguruan Tinggi Berdasarkan Pendekatan Keputusan Berkeadilan dengan Fuzzy Mamdani
}

\author{
Amsar', Rizal Munadi', Ramzi Adriman ${ }^{3}$ \\ ${ }^{1}$ Teknik Komputer, Politeknik Aceh Selatan \\ 1,2,3 Magister Teknik Elektro, Jurusan Teknik Elektro dan Komputer, Fakultas Teknik, Universitas Syiah Kuala \\ E-mail: amsar@poltas.ac.id, rizal.munadi@unsyiah.ac.id, ramzi.adriman@unsyiah.ac.id
}

\begin{abstract}
Abstrak
The scholarship is one of the funding schemes of study in an education system. Various models and names of scholarship schemes are offered on terms that have been determined by the scholarship provider. The essence of these conditions is the trust and confidence of the funders of the scholarship recipients and is projected to complete the study period as per the allocated funds. In general, funders are very concerned about the issue of academic qualification as one of the main indicators. However, for prospective students who wish to pursue higher education from coming from orphaned families and from less financially qualified families, with good academic qualifications, not yet a parameter in the selection process of scholarship recipients. Based on this fact, this problem would like to find solution in this research and submitted the selection model of scholarship with fair decision approach. This study aims to design a fair decision-making system as a tool for selection of scholarship recipients that prioritize the values of justice by prioritizing scholarship recipients from among orphans and poor. This research proposes two methods: Fuzzy Mamdani and weighting method, with 4 input parameters which are used as variables: children status and economic level, residence condition, children achievement and family dependent. Simulation testing performed by considering the parameters set is a more effective and efficient decision model for the prospective scholarship recipients. To obtain a competent recipient, then the screening process by ranking to be declared passed the selection and received as the recipient of scholarship in accordance with the number of quotas provided. This selection model becomes an alternative and provides opportunities for orphans and the poor to continue higher education and improve the human resource index as well as meet national education goals.
\end{abstract}

Keywords: Decision, Education System, Scholarship, Fuzzy Mamdani, Weighted Method.

\section{Pendahuluan}

Berdasarkan laporan World Economic Forum 2017, indeks sumber daya manusia Indonesia menempati posisi 65 dengan nilai 62,19 yang berada satu peringkat diatas Vietnam[1]. Ini menunjukkan posisi kompetensi dan daya saing sumber daya manusia perlu mendapat perhatian yang serius. Kualitas pendidikan merupakan indikator penting dalam menghasilkan sumber daya manusia yang bermutu dan berdaya saing. Di Indonesia, efektivitas pelaksanaan dan penerapan mutu terus dievaluasi pada semua jenjang pendidikan dan dinilai sebagai institusi terakreditasi oleh Badan Akreditasi Nasional. Perbaikan mutu ini merupakan harapan pendidikan nasional untuk menciptakan dan mengembangkan kualitas manusia Indonesia dengan sebuah mekanisme sistem pendidikan nasional yang berkualitas [2]. Dalam memberikan akselarasi pendidikan, peserta didik yang mempunyai kualifikasi akademik dan memenuhi persyaratan dengan standar tertentu, mendapatkan peluang untuk didanai melalaui program beasiswa. Umumnya, pertimbangan utama pemberi beasiswa adalah prestasi akademik saja sebagai faktor utama. sebagai contoh dalam pemberian beasiswa pendidikan, dimana beasiswa ini merupakan pemberian dari sebuah lembaga baik Negeri maupun swasta dalam menempuh pendidikan, bantuan, bantuan beasiswa dapat berupa uang, atau juga bebas semua administrasi kegiatan perkuliahan selama menempuh pendidikan. Untuk mendapatkan pendidikan yang berkualitas maka perlu seleksi sumber daya manusia dengan keputusan yang tepat.

Dalam penelitian ini dikaji tentang penentuan hasil dari proses penerimaan beasiswa sehingga keputusan yang diperoleh adil dan tanpa merugikan peserta lain. Untuk mencapai hal tersebut langkah pertama adalah membuat kategori variabel sebagai indikator pendukung dan menentukan bobot yang sesuai untuk mewakili kriteria dalam pengambilan keputusan [3]. Untuk itu perlu menyesuaikan dengan tujuan pendidikan nasional dalam melakukan seleksi penerima beasiswa, disamping 
itu juga perlu adanya mekanisme dalam proses pengambilan keputusan.

Penelitian untuk seleksi beasiswa dapat juga dilakukan menggunakan database query fuzzy, parameter yang diukur yaitu: IPK, Penghasilan orang tua, tanggungan orang tua, jumlah saudara kandung, kehadiaran selama perkuliahan, usia pada saat pendaftaran penerima beasiswa dan semester yang sedang berjalan. Penelitian ini bertujuan untuk mengurutkan peringkat calon penerima beasiswa sesuai dengan jumlah yang diterima [3].

Dari beberapa penelitian di atas, maka yang dilakukan dalam penelitian ini adalah membangun sistem pengambilan keputusan menggunakan Fuzzy Mamdani dan pembobotan untuk menghasilkan sebuah sistem pengambilan keputusan yang mempunyai nilai optimum sebagai alat bantu untuk proses seleksi penerimaan beasiswa.

Keputusan yang ditetapkan merupakan gabungan konsep-konsep dasar subjektivitas yang bertujuan untuk mengambil keputusan dari pengambangan metode yang ambiguitas menjadi beberapa kriteria untuk penetapan keputusan, teori keputusan adalah deskriptif ketika orang membuat keputusan dan diberitahukan kepada orang lain [4]. Sistem penunjang pengambilan keputusan berbasis teknologi merupakan gabungan antara manusia dan teknologi komputer, seiring dengan perkembangan teknologi, maka sistem pengambilan keputusan atau dikenal juga dengan Decision Support System (DSS) yang diharapkan mampu mengatasi persoalan yang rumit, baik terstruktur maupun tidak, sehingga menghasilkan keputusan yang tepat dan benar [5].

Untuk melakukan penelitian ini, maka model penelitian menggunakan model spiral, yang terdiri dari beberapa tahapan yaitu perencanaan, analisis dan desain, pembuatan prototype, pengujian dan penggabungan [6]. Penelitian menggunakan model spiral ini dipilih karena pengujian dilakukan secara berulang-ulang.

Keputusan yang diambil adalah hasil dari perangkingan data yang diinputkan ke dalam sistem yang dibangun untuk sebuah keputusan yang diharapkan, jadi setelah mendapatkan nilai masingmasing data, maka untuk mengurutkan data terbaik sangat efektif menggunakan sistem perangkingan sehingga keputusan yang ditetapkan mampu menghitung derajat dengan nilai data tertinggi dalam kumpulan data itu sendiri, maka data dengan nilai skor yang tinggi dijadikan urutan paling atas untuk diambil keputusan bahwa data tersebut lebih baik, sampai ada data lain lagi dengan derajat yang lebih tinggi dari data tersebut [7].

Banyak model-model program beasiswa yang ditawarkan oleh lembaga-lembaga tertentu untuk pendidikan dengan berbagai macam persyaratan seperti berikut ini:
A. DAAD Jerman

Lembaga pendidikan beasiswa Deutscher Akademischer Austauschdienst (DAAD) ini dibuka setiap tahun untuk calon mahasiswa dari Indonesia dengan persyaratan [7]:

1. Bekerja pada pemerintahan, BUMN atau swasta di negara berkembang.

2. Sudah menyelesaikan sarjana saat sudah bekerja.

3. Menyelesaikan gelar akademik dengan nilai di atas rata-rata serta memiliki pengalaman kerja profesional setidaknya dua tahun pada bidang terkait.

4. Gelar akademik yang telah diambil normalnya tidak lebih dari enam tahun.

5. Perkuliahan yang menggunakan bahasa Jerman: mengikuti DSH 2 atau TestDaF 4 dan harus selesai pada level A2.

Untuk perkuliahan yang menggunakan bahasa Inggris: skor IELTS (Band 6) atau TOEFL PBT 550, CBT 213, dan IBT 80.

\section{B. AMINEF}

American Indonesian Exchange Foundation (AMINEF) adalah sebuah yayasan yang didirikan tahun 1992. Model beasiswa yang dikelola oleh Aminef memiliki persyaratan sebagai berikut [9]:

1. WNI dan tidak memiliki kewarganegaraan ganda.

2. Memiliki kualitas kepemimpinan.

3. Memiliki pemahaman tentang kebudayaan Indonesia dan internasional.

4. Memiliki komitmen pada bidang studi pilihan.

5. Memiliki komitmen yang kuat untuk kembali ke Indonesia setelah menyelesaikan program Fulbright.

6. Pelamar bukan merupakan seorang karyawan dari AMINEF atau Kedutaan Besar AS atau Departemen Luar Negeri AS atau anggota keluarga dekat atau tergantung dari karyawan dari tempat-tempat di atas. Pelamar saat ini tidak terdaftar di lembaga pendidikan atau mengejar gelar di tempat lain.

7. Tidak menerima beasiswa lain pada saat aplikasi atau pada saat yang sama sebagai beasiswa AMINEF.

8. Tidak berniat untuk mengejar program serupa lain untuk gelar ganda.

9. Masih akan bekerja di lembaga minimal 5 tahun sebelum pensiun pada saat selesainya program beasiswa.

Bagi yang ingin mendapatkan beasiswa ini, pendaftar diminta untuk memiliki sertifikat 
Institutional Testing Program (ITP) TOEFL atau skor IELTS.

C. LPDP

Beasiswa Pendidikan Indonesia (BPI) Program Magister dan Doktoral adalah program beasiswa yang dibiayai oleh pemerintah Indonesia melalui pemanfaatan Dana Pengembangan Pendidikan Nasional (DPPN) dan dikelola oleh LPDP untuk pembiayaan studi lanjut pada program Magister atau program Doktoral di Perguruan Tinggi di dalam dan di luar negeri. Adapun persyaratan bagi sebagai berikut [10]:

a) Persyaratan Pendaftar Program Magister

1. Berbadan sehat dan bebas dari narkoba.

2. Mendapatkan rekomendasi dari atasan bagi yang sedang bekerja.

3. Memiliki dan memilih bidang keilmuan yang sesuai dengan bidang keilmuan yang menjadi sasaran LPDP.

4. Memilih program studi dan perguruan tinggi sesuai ketentuan LPDP.

5. Menandatangani semua surat pernyataan sesuai dengan ketentuan LPDP.

6. Batas usia pendaftar pada 31 Desember pada tahun pendaftaran yaitu:

- Masyarakat umum, Aparatur Sipil Negara (ASN)/PNS maksimum 35 tahun.

- Aparatur Sipil Negara (ASN)/PNS dengan jabatan fungsional sebagai Peneliti, Medis/Paramedis, dan Guru/Dosen maksimum 42 tahun.

7. Telah menyelesaikan studi S-1.

8. Tidak sedang atau telah menempuh studi degree/non degree (on going)

9. Memiliki Indeks Prestasi Kumulatif (IPK) dari jenjang studi sebelumnya dengan ketentuan:

a). IPK $\geq 3,0$ pada skala 4 atau yang setara bagi yang belum memiliki $L o A$ Unconditional.

b). IPK < 3,0 dapat melakukan pendaftaran jika memiliki LoA

c). LPDP lebih memprioritaskan kepada pendaftar dengan IPK $>3,0$.

10. Memiliki dokumen resmi sebagai bukti penguasaan bahasa Inggris yang diterbitkan oleh ETS atau IELTS yang masih berlaku atau bahasa asing lainnya yang ditentukan LPDP.

11. Pendaftar program Magister Dalam Negeri harus memiliki dokumen resmi bukti penguasaan bahasa Inggris.

b) Persyaratan Program Doktoral
Berikut ini diuraikan persyaratan Doktoral, diantaranya adalah sebagai berikut:

1. Berbadan sehat dan bebas dari narkoba.

2. Mendapatkan rekomendasi dari atasan bagi yang sedang bekerja.

3. Memiliki dan memilih bidang keilmuan yang sesuai dengan bidang keilmuan yang menjadi sasaran LPDP.

4. Memilih program studi dan perguruan tinggi sesuai dengan ketentuan LPDP.

5. Menandatangani semua surat pernyataan sesuai dengan ketentuan LPDP.

6. Batas usia pendaftar pada 31 Desember pada tahun pendaftaran yaitu:

a)Masyarakat umum, maksimum 40 tahun.

b) Aparatur Sipil Negara (ASN)/PNS, maksimum 42 tahun

c) Aparatur Sipil Negara (ASN)/PNS dengan jabatan fungsional sebagai Peneliti, Medis/Paramedis, dan Guru/Dosen maksimum 47 tahun.

6. Telah menyelesaikan studi S-2

7. Tidak sedang atau telah menempuh studi degree/non degree (on going).

8. Memiliki Indeks Prestasi Kumulatif (IPK) dari jenjang studi sebelumnya dengan ketentuan:

a) Sekurang-kurangnya 3,25 pada skala 4 bagi yang belum memiliki LoA Unconditional.

b) IPK yang dibawah 3,25 dapat melakukan pendaftaran jika memiliki LoA Unconditional.

c) LPDP lebih memprioritaskan kepada pendaftar dengan IPK diatas 3,25.

9. Memiliki dokumen resmi bukti penguasaan bahasa Inggris yang diterbitkan oleh ETS atau IELTS yang masih berlaku atau bahasa asing lainnya yang ditentukan LPDP.

10. Harus memilki dokumen resmi bukti penguasaan bahasa Inggris.

11. Pendaftar BPI Program Doktoral Luar Negeri harus memilki dokumen resmi bukti penguasaan bahasa Inggris

12. Pendaftar BPI Program Doktoral yang menyelesaikan studi dari Perguruan Tinggi Luar Negeri dengan menggunakan bahasa pengantar yang diakui oleh Perserikatan Bangsa-Bangsa (PBB) dikecualikan dari persyaratan sebagaimana dimaksud pada angka 11 dan angka 12, serta dibuktikan dengan salinan ijazah dengan masa berlaku 2 (dua) tahun sejak ijazah diterbitkan. 
Bidikmisi adalah bantuan biaya pendidikan bagi calon mahasiswa tidak mampu secara ekonomi dan memiliki potensi akademik baik sampai lulus tepat waktu. Syarat-syarat Bidikmisi adalah sebagai berikut [11]:

1. Siswa SMA/SMK/MA atau sederajat yang akan lulus pada tahun 2017.

2. Lulusan tahun 2016 yang bukan penerima Bidikmisi dan tidak bertentangan dengan ketentuan penerimaan mahasiswa baru di perguruan tinggi lain.

3. Usia paling tinggi pada saat mendaftar adalah 21 tahun.

4. Tidak mampu secara ekonomi.

5. Pendidikan orang Tua/Wali setinggitingginya S1 (Strata 1) atau Diploma 4.

6. Memiliki potensi akademik baik berdasarkan rekomendasi objektif dan akurat dari Kepala Sekolah.

7. Pendaftar difasilitasi untuk memilih salah satu diantara PTN atau PTS dengan ketentuan: PTN dengan pilihan seleksi masuk:
a. Seleksi Masuk Perguruan Tinggi Negeri (SNMPTN).
b. Seleksi Bersama Masuk Perguruan Tinggi Negeri (SBMTPN).
c. Seleksi mandiri PTN Politeknik, UT, dan Institut Seni dan Budaya PTS sesuai dengan pilihan seleksi masuk.

\section{E. LPSDM Aceh}

Program yang ditawarkan oleh Lembaga Peningkatan Sumber Daya Manusia (LPSDM) Aceh adalah program beasiswa keluarga miskin. Program ini dilaksanakan untuk meningkatkan pendidikan bagi putra-putri Aceh dalam rangka pengentasan kemiskinan diutamakan keluarga miskin dari akibat konflik, tsunami dan bencana alam yang terjadi di daerah kabupaten/kota dan tujuan dimaksud agar tidak terjadi kesalahan dalam pemilihan calon peserta. Berdasarkan acuan BPS yang telah menetapkan 14 (empat belas) kriteria keluarga miskin, dengan ciri-ciri rumah tangga miskin sebagai berikut [12]:

1. Luas lantai bangunan tempat tinggal kurang dari $8 \mathrm{~m}^{2}$ per orang.

2. Jenis lantai bangunan tempat tinggal terbuat dari tanah/bambu/kayu murahan.

3. Jenis dinding tempat tinggal terbuat dari bambu/rumbia/kayu berkualitas rendah/ tembok tanpa diplester.

4. Tidak ada fasilitas buang air besar/bersamasama dengan rumah tangga lain.

5. Sumber penerangan rumah tangga tidak menggunakan listrik.

6. Sumber air minum dari sumur/mata air tidak terlindung/sungai/air hujan.
7. Bahan bakar memasak sehari-hari adalah kayu bakar/arang/minyak tanah.

8. Hanya mengkonsumsi daging/susu/ayam satu kali dalam seminggu.

9. Hanya membeli satu stel pakaian baru dalam setahun.

10. Hanya sanggup makan sebanyak satu/dua kali dalam sehari.

11. Tidak sanggup membayar biaya pengobatan di puskesmas/poliklinik.

12. Sumber penghasilan kepala rumah tangga adalah: petani dengan luas lahan 0,5 ha. Buruh tani, nelayan, buruh bangunan, buruh perkebunan, atau pekerjaan lainnya dengan pendapatan di bawah Rp 600.000 per bulan.

13. Pendidikan kepala rumah tangga: tidak sekolah/tidak tamat SD/hanya SD.

14. Tidak memiliki tabungan/barang yang mudah dijual dengan nilai $\mathrm{Rp} 500.000$, seperti: sepeda motor (kredit/non kredit), emas, ternak, kapal motor, atau barang modal lainnya.

Jadi dengan beberapa penjelasan persyaratan pada jenis beasiswa yang sudah disebutkan di atas, maka penelitian ini, menawarkan persyaratan sederhana dan mudah untuk dipenuhi khususnya bagi yang kurang mampu, berprestasi dan dari kalangan anak yatim yang tinggal di daerah pedesaan sehingga hasil keputusan seleksi beasiswa mempunyai nilai yang optimal dan dapat berlandaskan keadilan.

\section{Metode dan Peralatan}

Pada penelitan ini mengunakan metode logika Fuzzy Mamdani dan metode pembobotan, perangkat lunak yang mendukung penelitian ini diantaranya komputer dengan spesifikasi yang cukup untuk menjalankan perangkat lunak dengan sistem operasi Windows 7 dan software Matlab sebagai alat untuk mendapatkan hasil output. Penelitian ini melibatkan responden sebanyak 30 orang mahasiswa sebagai dataset. Sampel data ini diperoleh dari hasil survei lapangan dari mahasiswa yang sudah mendapatkan beasiswa Yayasan Politeknik Aceh Selatan pada tahun 2016.

Untuk melakukan penelitian ini metode penelitian menggunakan motode Fuzzy Mamdani. Metode Fuzzy Mamdani ini sering disebut juga dengan metode Max-Min yang diperkenalkan oleh Ebrahim Mamdani pada tahun 1975 [13]. Dalam metode Mamdani ini ada beberapa tahapan yang harus dijalankan, yaitu:

1. Membuat himpunan Fuzzy

2. Merancang aturan (Aplikasi fungsi implikasi) berupa rule-rule yang menjadi proses pengambilan keputusan.

3. Komposisi aturan 
4. Defuzifikasi/penegasan dari tahapan 1 sampai dengan 3 di atas sebagai nilai akhir dari proses perhitungan dengan Fuzzy.

Secara umum proses perancangan Fuzzy Mamdani dapat dilihat pada Gambar 1.

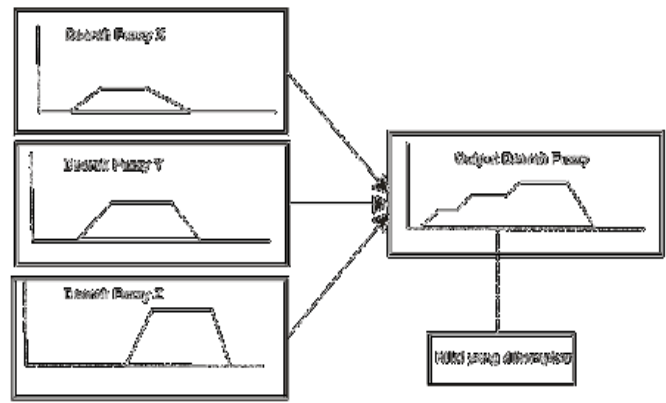

Gambar 1. Himpunan fuzzy input dan output

Pada tahap defuzzyfikasi dalam Fuzzy Mamdani aturan komposisi menggunakan metode centroid, metode ini merupakan solusi penegasan pada daerah himpunan Fuzzy dengan cara diambil titik pusat pada himpunan, untuk variabel kontinyu seperti dalam penelitian ini dapat menggunakan persamaan (1), sedangkan untuk variabel diskrit dapat menggunakan persamaan (2) berikut ini [13]:

$$
\begin{aligned}
& \mu(x)=\frac{\int_{a}^{b} x_{\mu}(x) d x}{\int_{a}^{b} \mu(x) d x} \\
& \mu(x)=\frac{\sum_{i=1}^{n} x_{i} \mu\left(x_{i}\right)}{\sum_{i=1}^{n} \mu\left(x_{i}\right)}
\end{aligned}
$$

Berdasarkan standar penerimaan mahasiswa beasiswa Politeknik Aceh Selatan tahun 2016 sebagai dasar variabel dalam penelitian ini maka, terdapat 4 parameter yang menjadi syarat dalam seleksi penerima beasiswa. Variabel dapat dinotasikan dengan $\left(\mathrm{P}_{\mathrm{i}}\right)$ dimana $\mathrm{i}=1,2,3$, dan 4 . Nilai bobot masing-masing variabel interval berkisar antara 0 sampai 100. Adapun keempat variabel ini disajikan dalam Tabel 1 sampai dengan Tabel 1 berikut ini:

Tabel 1. Variabel Status anak dan taraf ekonomi (P1), Anak Yatim (AY), Tidak Yatim (TY), Taraf Ekonomi (TE)

\begin{tabular}{|c|c|r|}
\hline $\mathrm{N}$ & \multicolumn{1}{|c|}{ Keterangan } & Nilai \\
\hline 1 & AY dan TE $\leq \operatorname{Rp~1.500.000~}$ & 100 \\
\hline 2 & AY dan TE $\leq \operatorname{Rp~2.500.000~}$ & 87,5 \\
\hline 3 & AY dan TE $\leq \operatorname{Rp~3.500.000~}$ & 75 \\
\hline 4 & AY dan TE $\leq \operatorname{Rp~4.500.000~}$ & 62,5 \\
\hline 5 & AY dan TE $>\operatorname{Rp~4.500.000~}$ & 50 \\
\hline 6 & TY dan TE $\leq \operatorname{Rp~1.500.000~}$ & 75 \\
\hline
\end{tabular}

\begin{tabular}{|c|l|r|}
\hline 7 & TY dan TE $\leq \operatorname{Rp} 2.500 .000$ & 62,5 \\
\hline 8 & TY dan TE $\leq \operatorname{Rp~} 3.500 .000$ & 50 \\
\hline 9 & TY dan TE $\leq \operatorname{Rp~4.500.000~}$ & 37,5 \\
\hline 10 & TY dan TE $>\operatorname{Rp} 4.500 .000$ & 25 \\
\hline 11 & AY dan TY dan TE $\geq$ Rp 10.000.000 & 0 \\
\hline
\end{tabular}

Tabel 2. Variabel Kondisi Rumah (P2)

\begin{tabular}{|c|l|r|}
\hline $\mathrm{N}$ & \multicolumn{1}{|c|}{ Keterangan } & Nilai \\
\hline 1 & Menumpang tipe rumah papan/kayu & 100 \\
\hline 2 & Kontrak tipe rumah papan/kayu & 90 \\
\hline 3 & Milik pribadi tipe rumah papan/kayu & 85 \\
\hline 4 & Menumpang tipe rumah semi & 80 \\
\hline 5 & Kontrak tipe rumah semi permanen & 75 \\
\hline 6 & Milik pribadi tipe rumah semi & 70 \\
\hline 7 & Menumpang tipe rumah permanen & 65 \\
\hline 8 & Kontrak tipe rumah permanen & 60 \\
\hline 9 & Milik pribadi tipe rumah permanen & 55 \\
\hline 10 & Menumpang tipe rumah permanen & 50 \\
\hline 11 & Kontrak tipe rumah permanen & 25 \\
\hline 12 & Milik pribadi tipe rumah permanen & 0 \\
\hline
\end{tabular}

Nilai prestasi akademik, yang diambil dari rapor sekolah tingkat SLTA semester 1 hingga 6, dimana $\mathrm{n}$ adalah jumlah peringkat/prestasi rangking lima besar, dengan rincian:

$$
\begin{array}{ll}
\text { Rangking } 1 & =\mathrm{n} \times 3 \\
\text { Rangking 2, } 3 & =\mathrm{n} \times 2 \\
\text { Rangking } 4,5 & =\mathrm{n} \times 1
\end{array}
$$

Sedangkan nilai prestasi non akademik diperoleh dari keaktifan siswa selama menempuh pendidikan di sekolah maupun diluar, dimana $\mathrm{n}$ adalah jumlah peringat/prestasi yang diperoleh dan dibuktikan dengan piagam penghargaan/sertifikat, rinciannya adalah sebagai berikut:

Prestasi tingkat Nasional $=\mathrm{n} \times 5$

Prestasi tingkat Provinsi $=\mathrm{n} \times 3$

Prestasi tingkat Kabupaten $/$ sekolah $=\mathrm{n} \times 1$

\begin{tabular}{|c|c|c|c|}
\hline No & $\begin{array}{l}\text { Interval nilai } \\
\text { akademik dan } \\
\text { non akademik }\end{array}$ & Nilai & Prestasi \\
\hline 1. & $\mathrm{P} 3 \geq 16$ & 100 & Akademik : \\
\hline 2. & $13 \leq \mathrm{P} 3<16$ & 90 & Rank.1 = $1=3$ \\
\hline 3. & $9 \leq \mathrm{P} 3<13$ & 85 & Rank. $2,3=\mathrm{n} \times 2$ \\
\hline
\end{tabular}

Variabel P3 terbagi atas tiga penilaian, yaitu nilai rata-rata UAN, prestasi akademik dan prestasi non akademik seperti yang disajikan dalam Tabel 3.

Tabel 3. Variabel Prestasi (P3) 


\begin{tabular}{|r|l|r|l|}
\hline 4. & $5 \leq \mathrm{P} 3<9$ & 70 & Rank. 4, $5=\mathrm{n} \times 1$ \\
\cline { 1 - 3 } 5. & $3 \leq \mathrm{P} 3<5$ & 50 & Non Akademik : \\
6. & $\mathrm{P} 3<3$ & 0 & $\begin{array}{l}\text { Nasional =n x 5 } \\
\text { Provinsi =n x 3 } \\
\text { Kabupate =n x 1 }\end{array}$ \\
\cline { 1 - 2 } & \multicolumn{3}{|l|}{ Nilai P3 = (Rata-rata UAN + Nilai Prestasi)/2 } \\
\hline
\end{tabular}

Dalam variabel P3 nilai rata-rata $\mathrm{UAN}>50$, tidak bisa dilanjutkan seleksi variabel berikutnya jka rata-rata $U A N \leq 50$. Prestasi terdiri dari nilai akademik dan non akademik, nilai akademik ini diambil dari rapor sekolah tingkat SLTA semester IVI dan $n$ adalah jumlah peringkat/prestasi rangking 5 (lima) besar, sedangkan nilai prestasi non akademik diperoleh dari keaktifan siswa selama menempuh pendidikan di sekolah maupun diluar sekolah, dimana $n$ adalah jumlah peringkat/prestasi yang diperoleh yang dibuktikan dengan piagam penghargaan/sertifikat.

Tabel 4. Variabel Tanggungan keluarga (P4)

\begin{tabular}{|c|c|c|}
\hline No. & Keterangan & Nilai \\
\hline 1 & Jumlah tanggungan $>7$ orang & 100 \\
\hline 2 & Jumlah tanggungan 6 - & 80 \\
\hline 3 & Jumlah tanggungan 4 -5 & 40 \\
\hline 4 & Jumlah tanggungan 2 - 3 & 20 \\
\hline 5 & Jumlah tanggungan 1 orang & 0 \\
\hline
\end{tabular}

Sistem pengambilan keputusan dengan menetapkan 4 parameter masuk dalam persyaratan calon penerima beasiswa, keputusan ini baru dikatakan adil apabila semua persyaratan terpenuhi dan nilai pada setiap parameter yang diinputkan menjadi penentu pada keputusan akhir yang diambil berdasarkan hard copy/berkas yang dikumpulkan oleh peserta seleksi kepada panitia seleksi beasiswa. Dengan kata lain dari sistem pengambilan keputusan berkeadilan adalah keselarasan dengan hakikat adil itu sendiri, adil juga dapat dikatakan sebagai suatu sikap dan tindakan yang tidak berpihak dalam memutuskan hasil akhir kelulusan penerima beasiswa.

Pada pengujian dengan menggunakan metode Fuzzy Mamdani akan diseleksi jumlah penerima jika kuota yang disediakan sebanyak 10 orang. Pengujian dengan menggunakan metode Fuzzy Mamdani ini dilakukan dengan menggunakan software matlab, proses input-output ditunjukkan pada Gambar 2.

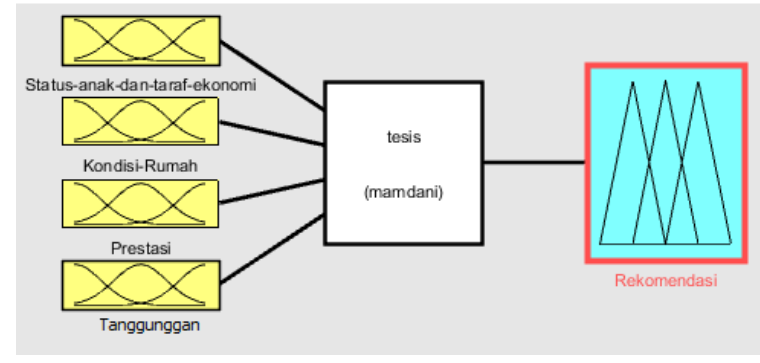

Gambar 2. Input-output sistem Fuzzy Mamdani

\section{Hasil dan Pembahasan}

Pengujian ini menggunakan metode Fuzzy Mamdani, yang dijadikan model seleksi beasiswa berkeadilan ini memperioritaskan kelulusan untuk penerimaan adalah calon dengan status anak yatim dan tingkat ekonomi yang lemah. Dalam penelitian ini data yang akan diuji dapat ditampilkan dalam Tabel 5 berikut ini:

Tabel 5. Data penelitian

\begin{tabular}{|c|c|c|c|c|c|}
\hline \multirow{2}{*}{ No } & \multirow{2}{*}{$\begin{array}{l}\text { Nama/ } \\
\text { Inisial }\end{array}$} & \multicolumn{4}{|c|}{ Variabel } \\
\hline & & $\mathrm{P} 1$ & $\mathrm{P} 2$ & P3 & P4 \\
\hline 1 & $\mathrm{ABDM}$ & 87,50 & 80,00 & 64,45 & 100,00 \\
\hline 2 & ANMZ & 75,00 & 70,00 & 61,00 & 50,00 \\
\hline 3 & EKSF & 75,00 & 80,00 & 64,30 & 50,00 \\
\hline 4 & FMUH & 100,00 & 75,00 & 73,00 & 50,00 \\
\hline 5 & FTNI & 50,00 & 90,00 & 83,00 & 50,00 \\
\hline 6 & HTFR & 100,00 & 90,00 & 59,50 & 50,00 \\
\hline 7 & IMAZ & 100,00 & 65,00 & 71,65 & 50,00 \\
\hline 8 & JEDA & 100,00 & 55,00 & 71,45 & 50,00 \\
\hline 9 & KDMS & 37,50 & 75,00 & 62,50 & 50,00 \\
\hline 10 & MSFD & 37,50 & 55,00 & 29,25 & 50,00 \\
\hline 11 & MYNS & 75,00 & 55,00 & 67,50 & 100,00 \\
\hline 12 & MZBR & 50,00 & 90,00 & 35,50 & 100,00 \\
\hline 13 & MLGT & 37,50 & 55,00 & 68,50 & 75,00 \\
\hline 14 & MFDH & 75,00 & 75,00 & 83,00 & 75,00 \\
\hline 15 & NKFZ & 75,00 & 55,00 & 63,30 & 50,00 \\
\hline 16 & NVSR & 50,00 & 55,00 & 59,00 & 100,00 \\
\hline 17 & OVKA & 25,00 & 75,00 & 75,00 & 100,00 \\
\hline 18 & RNWT & 75,00 & 80,00 & 58,85 & 50,00 \\
\hline 19 & RDTI & 75,00 & 70,00 & 84,60 & 50,00 \\
\hline 20 & RZFZ & 75,00 & 75,00 & 58,75 & 75,00 \\
\hline 21 & RZMT & 75,00 & 100,00 & 72,00 & 25,00 \\
\hline 22 & RSNT & 50,00 & 70,00 & 63,50 & 100,00 \\
\hline 23 & SNDV & 50,00 & 75,00 & 67,15 & 100,00 \\
\hline 24 & STFT & 87,50 & 75,00 & 56,50 & 100,00 \\
\hline 25 & STRN & 75,00 & 65,00 & 75,50 & 50,00 \\
\hline 26 & SPNA & 75,00 & 65,00 & 59,00 & 50,00 \\
\hline
\end{tabular}




\begin{tabular}{|l|l|r|c|c|c|}
\hline \multirow{2}{*}{ No } & \multirow{2}{*}{$\begin{array}{l}\text { Nama/ } \\
\text { Inisial }\end{array}$} & \multicolumn{4}{|c|}{ Variabel } \\
\cline { 3 - 6 } & & \multicolumn{1}{|c|}{ P1 } & \multicolumn{1}{|c|}{ P2 } & \multicolumn{1}{c|}{ P3 } & \multicolumn{1}{c|}{ P4 } \\
\hline 27 & SRDY & 100,00 & 75,00 & 77,50 & 75,00 \\
\hline 28 & SHDI & 75,00 & 75,00 & 64,85 & 50,00 \\
\hline 29 & ULAK & 75,00 & 75,00 & 72,50 & 50,00 \\
\hline 30 & ZLFM & 100,00 & 75,00 & 61,65 & 25,00 \\
\hline
\end{tabular}

\subsection{Hasil pengujian dengan menggunakan metode} Fuzzy Mamdani

Dari penyajian dataset pada Tabel 5 di atas, output yang diputuskan untuk diterima adalah responden yang memenuhi unsur yang ditetapkan dan mempunyai nilai optimum jika dibandingkan dengan responden lainnya. Setelah dilakukan pengujian dari dataset pada penelitian ini, maka urutan yang tepat untuk diberikan beasiswa dari 30 responden adalah peserta yang terdapat pada Tabel 6 dengan menggunakan metode Fuzzy Mamdani.

Tabel 6. Hasil output metode Fuzzy Mamdani

\begin{tabular}{|l|l|c|l|}
\hline No & $\begin{array}{c}\text { Nama/ } \\
\text { Inisial }\end{array}$ & Nilai & Keputusan \\
\hline 1 & SRDY & 89,24 & Diterima \\
\hline 2 & ABDM & 88,41 & Diterima \\
\hline 3 & FMUH & 87,21 & Diterima \\
\hline 4 & HTFR & 86,88 & Diterima \\
\hline 5 & IMAZ & 85,55 & Diterima \\
\hline 6 & RZMT & 84,43 & Diterima \\
\hline 7 & STFT & 83,92 & Diterima \\
\hline 8 & ZLFM & 81,47 & Diterima \\
\hline 9 & MFDH & 80,14 & Diterima \\
\hline 10 & JEDA & 77,50 & Diterima \\
\hline
\end{tabular}

Secara keseluruhan Grafik output perangkingan dari data penelitian dengan Fuzzy Mamdani dapat dilihat pada Gambar 3.

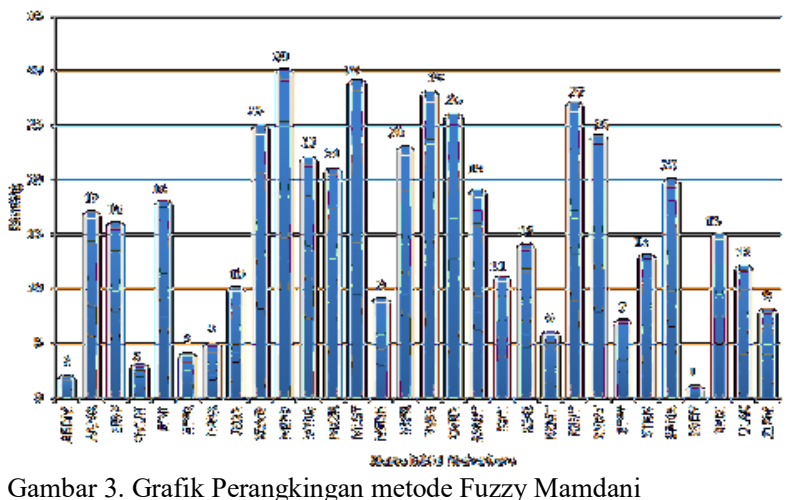

\section{Simpulan}

Model keputusan penerimaan beasiswa dalam penelitian yang dilakukan ini dapat menjadi tolak ukur untuk sebuah sistem yang dibangun dalam seleksi beasiswa secara adil dan tepat sasaran sesuai dengan tujuan pendidikan nasional. Dari pengujian yang sudah dilakukan baik menggunakan metode Fuzzy Mamdani menghasilkan keputusan akhir untuk yang dinyatakan lulus seleksi bagi penerima beasiswa. Keberhasilan dalam implementasi proses seleksi calon penerima beasiswa akan lebih transparan dan objektif apalagi melalui azas berkeadilan, keputusan yang ditetapkan juga berdasarkan pengujian dengan mengambil nilai yang optimal setelah melalui proses perangkingan data dan jumlah yang diterima sebagai batas rangking, sehingga peserta yang lulus benar-benar murni dari persyaratan dan pertimbangan yang matang sehingga penerima beasiswa yang memiliki kualifikasi akademik yang bagus dan optimal berdasarkan bukti fisik dari berkas-berkas persyaratan yang diserahkan kepada tim seleksi beasiswa. Hasil dari penelitian ini merupakan solusi alternatif bagi penerima mahasiwa dan dapat diterapkan pada seleksi penerimaan beasiswa yang lebih mengutamakan kepada anak yatim dan miskin.

\section{Daftar Pustaka}

[1] Anonymous, The Global Human Capital Report 2017: Preparing People for the future of work, Insight Report, World Economic Forum, 2017.

[2] A.H.R.Tilaar, Pembenahan Pendidikan Nasional. Jakarta: Rineka Cipta, 2002.

[3] Fadilah, "Model Penunjang Keputusan Penentuan Penerima Beasiswa Berprestasi Berbasis SAW di STMIK Banjarbaru," IJSE - Indonesian Journal on Software Engineering., vol. 2, no. 1, pp. 1-6, 2016.

[4] A. Hadi-vencheh and M. Mirjaberi, "SeclusionFactor Method to Solve Fuzzy-Multiple Criteria Decision-Making Problems," IEEE Transactions On Fuzzy Systems, vol. 19, no. 2, pp. 201-209, April 2011.

[5] H. Listiyono, Sunardi, and T. Khristianto, "Rekayasa Perangkat Lunak Sistem Pendukung Keputusan Pemberian Kredit (Studi Kasus pada BPR Argo Dana Semarang)," Jurnal Teknologi Informasi DINAMIK, vol. 16, no. 1, pp. 72-76, 2011.

[6] H. Kusmiati and M. Ansori, "Aplikasi Pemasangan Layanan Reguler Smart PT . PLN ( Persero ) menggunakan Spiral Model," JSM STMIK Mikroskil, vol. 16, no. 1, pp. 61-71, 2015.

[7] Shyi-Ming Chen and Jia-An Hong, "Fuzzy Multiple Attributes Group Decision-Making Based on Ranking Interval Type-2 Fuzzy Sets and the TOPSIS Method," IEEE Transactions On Systems, Man, And Cybernetics: Systems, vol. 44, no. 12, pp. 
1665-1673, 2014.

[8] DAAD Indonesia, "Deutscher Akademischer Austauschidienst German Academic Exchange Service," 2017. [Online]. Available: http://www.daadjkt.org/index.php?studienkolleg-5.

[9] Aminef, "Beasiswa Fulbright," 2017. [Online]. Available: www.aminef.or.id.

[10] LPDP, "Beasiswa Pendidikan Indonesia," 2017. [Online]. Available: www.beasiswa.lpdp.kemenkeu.go.id.

[11] Bidikmisi, "Direktorat Pembelajaran dan Kemahasiswaan," 2017. [Online]. Available: www.bidikmisi.zendesk.com.

[12] LPSDM Aceh, "Beasiswa LPSDM Aceh," 2017. [Online].

Available: http://www.lpsdm.acehprov.go.id/.

[13] S. Kusumadewi and H. Purnomo, Aplikasi Logika Fuzzy untuk Pendukung Keputusan. Yogyakarta: Graha Ilmu, 2013. 